\title{
Analisis Pemilihan Supplier Chemical Boilout Menggunakan Metode AHP (Analytical Hierarchy Process) Di Seksi Paper Machine\#6.
}

\author{
Satriardi ${ }^{1,}$ Martinus. $\mathbf{S}^{2}$ \\ ${ }^{1,2}$ Teknik Industri UMRI \\ Kampus : Jl. Ahmad Dahlan, 88 Pekanbaru Telp. (0761) 35008, fax. (0761) 35008 \\ ${ }^{1}$ satriadi@umri.ac.id, ${ }^{2} 170103009 @$ student.umri.ac.id
}

\begin{abstract}
This study aims to determine the best criteria on which to base the selection of alternative Chemical Boilout suppliers for Paper Machine \# 6 dissection and to determine the best supplier to be selected for the Chemical Boilout supplier. The benefit of this research is to improve the consistency of run-ability by reducing the lost time sheet break and paper rejects. The method used is data processing using AHP (Analytical Hierarchy Process) and data collection by means of observation, interviews and questionnaires. The results of this study indicate the criteria for supplier selection, namely quality, price, supplier performance and guarantee of product claims. Then produce a weight for each alternative supplier, in order, namely kemira supplier with a weight of 30.627\%, buckman with a weight of 29.973\%, solenis with a weight of $21.608 \%$ and amazone with a weight of $17.792 \%$. therefore for the best supplier and will be recommended to be selected in the upcoming tender process is the supplier Kemira.
\end{abstract}

Keywords: Criteria, Alternative, Chemical Boilout, Supplier

\begin{abstract}
Abstrak
Penelitian ini bertujuan untuk mengetahui kriteria-kriteria terbaik yang menjadi dasar pemilihan alternatif supplier Chemical Boilout diseksi Paper Machine\#6 dan menentukan supplier terbaik yang akan dipilih untuk pemasok Chemical Boilout. Manfaat dari penelitian ini dapat meningkatkan konsistensi run-ability dengan berkurangnya lost time sheet break dan kertas reject. Metode yang digunakan adalah pengolahan data dengan menggunakan AHP (Analytical Hierarchy Process) dan pengumpulan data dengan cara observasi, wawancara dan kuisioner. Hasil Penelitian ini menunjukkan kriteria-krieria pemilihan supplier yaitu kualitas, harga, performance supplier dan garansi klaim produk. kemudian menghasilkan bobot pada setiap alternatif supplier, secara berurut yaitu supplier kemira dengan bobot 30,627 \%, buckman dengan bobot $29,973 \%$, solenis dengan bobot $21,608 \%$ dan amazone dengan bobot $17,792 \%$. maka dari itu untuk supplier terbaik dan akan direkomendasikan untuk dipilih pada proses tender mendatang adalah supplier kemira.
\end{abstract}

Kata Kunci : Kriteria, Alternatif, Chemical Boilout, Supplier

\section{Pendahuluan}

\subsection{Latar Belakang}

PT. Indah Kiat Pulp \& Paper, Tbk Perawang merupakan perusahaan manufaktur yang bergerak di bidang pulp \& paper. Penelitian di lakukan di departemen produksi pembuatan kertas yaitu Paper Machine\#6 (PPM\#6). Setiap bulannya di PPM\#6 dilakukan kegiatan annual shutdown. Pada proses shutdown PPM\#6, terdapat proses chemical boilout yang dilakukan untuk membersihkan kotoran yang mengendap didalam saluran pipa aliran bahan kimia bagian chemical, medapatkan suhu ruangan dan mendapatkan ph yang tepat sebelum bahan kimia akan diisi kembali saat start up. Tetapi seringkali endapan slime yang sudah dibersihkan kembali menumpuk sebelum 2 bulan, sehingga berimbas pada besarnya lost time break dengan reason hole dan besarnya jumlah roll reject yang terclassify dirty.

Berikut adalah data lost time dan roll reject selama lima tahun terhitung dari tahun 2016 -2020. 
Tabel 1 Data lost time dan roll reject PPM\#6.

\begin{tabular}{|c|c|c|c|c|}
\hline \multirow{2}{*}{ No } & \multirow{2}{*}{ Tahun } & Lost Time (Minutes) & \multicolumn{2}{c|}{ Paper Reject (Ton) } \\
\cline { 3 - 5 } & & Sheet Break & Holes & Dirty \\
\hline 1 & 2016 & 10.915 & 12 & 4 \\
\hline 2 & 2017 & 8.902 & 01.07 & 7 \\
\hline 3 & 2018 & 6.525 & 15 & 193.05 .00 \\
\hline 4 & 2019 & 9.864 & 20 & 16.03 \\
\hline 5 & 2020 & 7.565 & 48 & 90.07 .00 \\
\hline
\end{tabular}

Sumber : IKPP, 2020

Dari data diatas terlihat begitu tidak konsistennya proses produksi dikarenakan banyaknya jumlah lost time dan reject .

Supplier chemical boilout memegang peranan penting, selama ini manajemen PPM\#6 belum memiliki metode dan pertimbangan yang tetap dalam memilih supplier, sehingga dalam memilih supplier cenderung menggunakan feeling tanpa pertimbangan yang tepat. oleh karena itu perlu dilakukan penelitian dan identifikasi untuk menentukan supplier yang tepat dengan menggunakan metode AHP (Analytical Hierarchy Process) agar meminimalkan lost time dan reject produk.

\subsection{Tujuan Penelitian}

\section{Berikut adalah tujuan penelitian ini :}

1. Mengetahui kriteria kriteria terbaik dan bobotnya yang menjadi dasar pemilihan alternatif pada metode AHP.

2. Menentukan supplier terbaik berdasarkan kriteria menggunakan metode AHP.

\subsection{Tinjauan Pustaka}

\subsubsection{Analitycal Hierarchy Process (AHP)}

Analitycal Hierarchy Process (AHP) dikembangkan oleh Dr. Thomas L. Saaty dari Wharton School of Business pada tahun 1970-an untuk mengelompokkan informasi dan menentukan dalam memilih alternatif yang paling disukai (Saaty, 1983).

\subsubsection{Prinsip Dasar AHP}

Dalam menyelesaikan masalah dengan menggunakan analisa berpikir logis pada AHP, ada beberapa prinsip AHP yang harus dipahami dan diperhatikan (Saaty, 1983), yaitu:
1. Dekomposisi atau decomposition

Merupakan memecahkan atau membagi problema yang utuh menjadi unsur-unsurnya ke bentuk hirarki proses pengambilan keputusan, dimana setiap unsur atau elemen saling berhubungan.

\section{Comparative Judgement}

Comparative judgement dilakukan dengan penilaian tentang kepentingan relatif dua elemen pada suatu tingkat tertentu dalam kaitannya dengan tingkatan diatasnya.

3. Synthesis of priority

Synthesis of priority dilakukan dengan eigen vector method untuk mendapatkan bobot relatif bagi unsure-unsur pengambilan keputusan atau dengan kata lain dengan mengalikan prioritas lokal dengan prioritas dari kriteria yang bersangkutan di level atasnya dan menambahkannya ke tiap elemen dalam level yang dipengaruhi kriteria.

4. Logical Consistency

Tahap ini dicapai dengan mengagresikan seluruh eigen vector yang diperoleh dari berbagai tingkatan hirarki dan selanjutnya diperoleh suatu vektor composite tertimbang yang menghasilkan urutan pengambilan keputusan.

\subsubsection{Tahapan Perhitungan AHP}

1. Penyusunan struktur hirarki masalah

Hirarki masalah disusun untuk membantu proses pengambilan keputusan dengan memperhatikan seluruh elemen keputusan yang terlibat dalam sistem. 


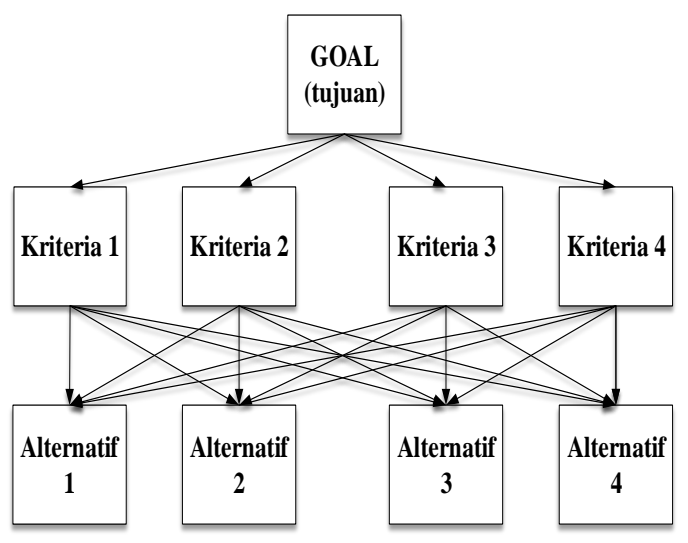

Gambar 1. Struktur Hirarki AHP Sumber: Thomas L. Saaty, 1994

2. Mendefinisikan perbandingan berpasangan dengan menentukan prioritas.

Tujuannya adalah untuk mengetahui tingkat kepentingan pihak- pihak yang berkepentingan dalam permasalahan terhadap kriteria dan struktur hirarki atau sistem secara keseluruhan.

Tabel 2 Matriks Perbandingan Pasangan

\begin{tabular}{|l|l|l|l|l|l|}
\hline $\mathrm{C}$ & $\mathrm{A}_{1}$ & $\mathrm{~A}_{2}$ & $\mathrm{~A}_{3}$ & $\ldots$. & $\mathrm{A}_{\mathrm{n}}$ \\
\hline $\mathrm{A}_{1}$ & $\mathrm{a} 11$ & $\mathrm{a} 12$ & $\mathrm{a} 13$ & & $\mathrm{a} 1 \mathrm{n}$ \\
\hline $\mathrm{A}_{2}$ & $\mathrm{a} 21$ & $\mathrm{a} 22$ & $\mathrm{a} 23$ & & $\mathrm{a} 2 \mathrm{n}$ \\
\hline $\mathrm{A}_{3}$ & $\mathrm{a} 31$ & $\mathrm{a} 32$ & $\mathrm{a} 33$ & & $\mathrm{a} 3 \mathrm{n}$ \\
\hline$\ldots$. & & & & & $\ldots$. \\
\hline $\mathrm{An}$ & $\mathrm{an} 1$ & $\mathrm{an} 2$ & $\mathrm{an} 3$ & $\ldots$. & $\mathrm{ann}$ \\
\hline
\end{tabular}

Sumber: Thomas L. Saaty, 1994
Tabel 3 Skala Penilaian Perbandingan Pasangan

\begin{tabular}{|c|l|l|}
\hline \begin{tabular}{c} 
Skala $\begin{array}{c}\text { Tingkat } \\
\text { kepentingan }\end{array}$ \\
\hline 1
\end{tabular} & \multicolumn{1}{|c|}{ Definisi } & \multicolumn{1}{|c|}{ Keterangan } \\
pentingnya & $\begin{array}{l}\text { Kedua elemen mempunyai } \\
\text { pengaruh yang sama }\end{array}$ \\
\hline 3 & $\begin{array}{l}\text { Sedikit lebih } \\
\text { penting }\end{array}$ & $\begin{array}{l}\text { Pengalaman dan penilaian sedikit } \\
\text { memihak satu elemen } \\
\text { dibandingkan dengan pasangannya }\end{array}$ \\
\hline 5 & Lebih penting & $\begin{array}{l}\text { Pengalaman dan penilaian sangat } \\
\text { memihak satu elemen dibandingkan } \\
\text { dengan pasangannya }\end{array}$ \\
\hline 7 & $\begin{array}{l}\text { Sangat } \\
\text { penting }\end{array}$ & $\begin{array}{l}\text { Satu elemen sangat disukai dan } \\
\text { secara praktis dominasinya sangat } \\
\text { nyata dibandingkan dengan } \\
\text { pasangannya }\end{array}$ \\
\hline 9 & $\begin{array}{l}\text { Mutlak lebih } \\
\text { penting }\end{array}$ & $\begin{array}{l}\text { Satu elemen terbukti mutlak lebih } \\
\text { disukai dibandingkan dengan } \\
\text { pasangannya, pada tingkat } \\
\text { keyakinan yang tertinggi }\end{array}$ \\
\hline $2,4,6,8$ & Nilai tengah & $\begin{array}{l}\text { Diberikan bila terdapat keraguan } \\
\text { penilaian antara dua penilaian yang } \\
\text { berdekatan }\end{array}$ \\
\hline kebalikan & Aila aktivitas i memperoleh suatu \\
$\mathrm{A}_{\mathrm{ij}}=1 / \mathrm{A}_{\mathrm{ij}}$ & $\begin{array}{l}\text { angka bila dibandingkan dengan } \\
\text { aktivitas maka memiliki nilai } \\
\text { kebalikannya bila } \\
\text { dibandingkan }{ }_{\mathrm{i}}\end{array}$ \\
\hline
\end{tabular}

\section{Sumber: Thomas L. Saaty, 1994}

3. Perhitungan Eigenvalue

Dengan cara membagi nilai dari setiap elemen didalam matriks yang berpasangan dengan nilai total dari setiap kolom.

Berikut adalah rumus yang digunakan:

$\mathrm{R} 1 \mathrm{n}=\frac{a 1 n}{a 1 n+a 2 n+a 3 n+\ldots}$

Dimana :

$\mathrm{R}=$ Perhitungan nilai eigen / matriks normalisasi

$\mathrm{a}=$ Elemen matriks

4. Perhitungan Eigen Vektor

dengan cara rata-rata tiap kriteria diperoleh dari rata-rata baris dari matriks ternormalisasi. Rata-rata diperoleh dari jumlah element tiap baris dibagi jumlah kriteria. Rumus pencarian vektornya prioritas adalah

$\mathrm{W}=\left[\begin{array}{c}\frac{r 11+r 12+r 13+r 1 n}{n} \\ \frac{r 21+r 22+r 23+r 2 n}{n} \\ \vdots \\ \frac{r n 1+r n 2+r n 3+r n n}{n}\end{array}\right]$ 
Dimana :

$\mathrm{W}=$ Vektor prioritas

$\mathrm{r}=$ Elemen matriks eigen

5. Konsistensi

Pengukuran konsistensi ini dimaksudkan untuk melihat ketidakkonsistenan respon yang diberikan responden. Jika CR $<0,1$ maka nilai perbandingan berpasangan pada matriks kriteria yang diberikan konsisten. Jika CR > 0,1 maka maka nilai perbandingan berpasangan pada matriks kriteria yang diberikan tidak konsisten.

Berikut adalah tahap konsistensi

- Menentukan $\lambda$ max

$\lambda$ maks $=[(\mathrm{W} 1 \mathrm{xN} 1)+(\mathrm{W} 2 \mathrm{xN} 2)+(\mathrm{WnxNn})]$ ...... (I.3)

Dimana :

$\mathrm{W}=$ rata rata nilai eigen perbaris

$\mathrm{N}=$ jumlah elemen matriks perbandingan pasangan perkolom.

- Menentukan Consistency Index (CI)

$\mathrm{CI}=(\lambda$ maks $-\mathrm{n}) /(\mathrm{n}-1)$

Dimana :

$\mathrm{CI}=$ indeks konsistensi

$\lambda$ maks $=$ eigenvalue maksimum

$\mathrm{n} \quad=$ orde matriks

- Menentukan Consistency Ratio (CR)

$\mathrm{CR}=\mathrm{CI} / \mathrm{RI}$

Dengan Tabel RI

Tabel 4. Random Consistency Index (RI)

\begin{tabular}{|l|l|l|l|l|l|l|l|l|l|l|}
\hline $\mathrm{N}$ & 1 & 2 & 3 & 4 & 5 & 6 & 7 & 8 & 9 & 10 \\
\hline RI & 0 & 0 & 0,58 & 0,9 & 1,12 & 1,24 & 1,32 & 1,41 & 1,45 & 1,49 \\
\hline
\end{tabular}

Sumber: Thomas L. Saaty, 1994

6. Menetapkan supplier terbaik

Setelah mengetahui vektor prioritas atau rata rata dari masing-masing kriteria dan alternatif supplier, langkah terakhir mengagresikan semua bobot dari tiap kriteria terhadap masing-masing alternatif. maka didapatlah rangking atau peringkat supplier terbaik untuk semua kriteria.

\section{Metodologi Penelitian}

\subsection{Waktu dan Tempat}

Waktu penelitian dari bulan Oktober sampai November 2020 Penelitian ini dilakukan di Seksi PPM\#6, PT Indah Kiat Pulp \& Paper Perawang.

\subsection{Objek Penelitian}

Objek pada penelitian ini adalah Supplier chemical boilout yang terdiri dari kemira, solenis, buckman dan amazone

\subsection{Pengumpulan Data}

Dalam pengumpulan data, metode yang digunakan sebagai berikut:

1.Observasi

Pengamatan langsung di seksi PPM\#6 selama satu bulan efektif terutama pada bagian proses boilout saat shut down.

\section{Wawancara}

Pengambilan data dengan melakukan wawancara/lisan dengan narasumber yang berhubungan langsung dengan expert di seksi PPM\#6.

3. Studi Literatur

Pengumpulan data dengan mencari informasi yang berkaitan dengan chemical boilout, AHP dan kualitas. Baik yang berada di perusahaan maupun yang beredar di buku, jurnal dan internet.

\subsection{Bahan dan Peralatan}

Bahan penelitian ini adalah literatur literatur yang digunakan sebagai acuan dalam melakukan penelitian. Dan peralatan yang digunakan dalam menunjang penelitian ini adalah handphone, buku, laptop dan kamera. 


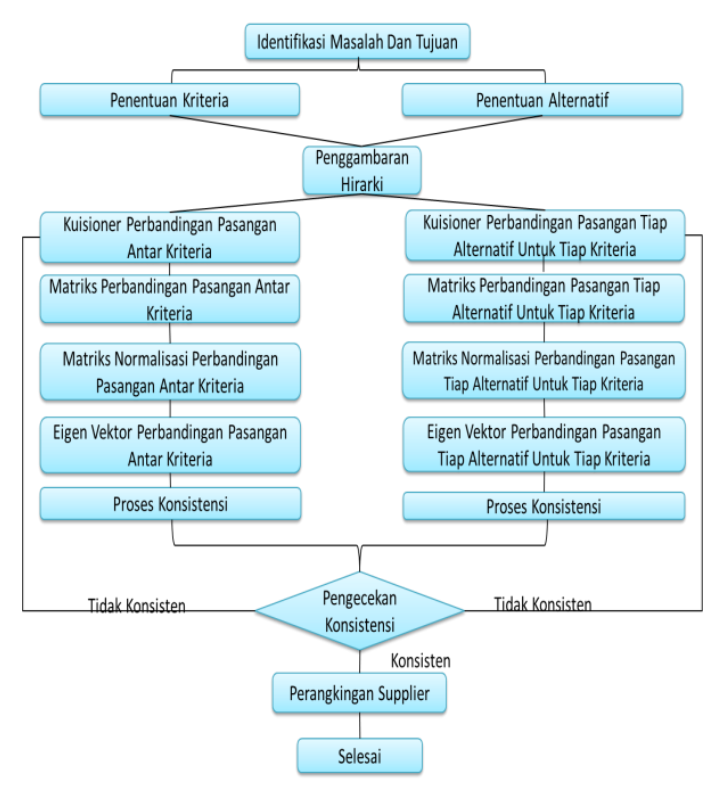

Gambar 2 Diagram Pemilihan Supplier Chemical boilout di Seksi PPM\#6 Sumber : IKPP, 2020

\section{Hasil dan Pembahasan}

Dalam menyelesaikan masalah dengan menggunakan analisa berpikir logis pada AHP, dengan menentukan Decompotion, Comparative Judgement, Syntesis Of Priority dan Logical Consistency (Saaty, 1983).

\subsection{Dekomposisi atau decomposition}

Decomposition adalah memecahkan atau membagi problema yang utuh menjadi unsur-unsurnya ke bentuk hirarki proses pengambilan keputusan, dimana setiap unsur atau elemen saling berhubungan.

1. Penentuan Tujuan

Tujuan atau level 0 dari hirarki ini adalah pemilihan supplier PPM\#6.

2. Menentukan Kriteria Pemilihan Supplier

Berikut adalah kriteria pemilihan supplier yang ditentukan melalui proses wawancara dengan ekspert/PIS area paper machine.

Tabel 5 Kriteria Pemilihan Supplier

\begin{tabular}{|c|c|l|}
\hline No. & KRITERIA & \multicolumn{1}{c|}{ DES KRIPSI } \\
\hline \multirow{2}{*}{1} & Kualitas & $\begin{array}{l}\text { Kemampuan supplier dalam memenuhi } \\
\text { spesifikasi produk Soda (NaOH). }\end{array}$ \\
\cline { 3 - 3 } & $\begin{array}{l}\text { Kemampuan Soda dalam mencapai Alkalinity, } \\
\text { PH, dan Temperature pada saat proses } \\
\text { Chemical Boilout. }\end{array}$ \\
\hline 2 & Harga & $\begin{array}{l}\text { Harga yang paling murah yang ditawarkan } \\
\text { untuk produk soda (NaOH). }\end{array}$ \\
\hline 3 & $\begin{array}{c}\text { Garansi } \\
\text { dan Klaim } \\
\text { Produk }\end{array}$ & $\begin{array}{l}\text { Garansi atau jaminan produk. } \\
\text { Kemudahan dalam melakukan klaim jika terjadi } \\
\text { cacat produk atau kualitas produk tidak bagus. }\end{array}$ \\
\hline \multirow{2}{*}{$\begin{array}{c}\text { Performa } \\
\text { nce }\end{array}$} & $\begin{array}{l}\text { Kemampuan dalam pemenuhan permintaan } \\
\text { terhadap kuantitas produk. }\end{array}$ \\
\cline { 3 - 4 } & $\begin{array}{l}\text { Supplier } \\
\text { Performa, pelayanan, dan tanggung jawab } \\
\text { supplier. }\end{array}$ \\
\cline { 3 - 4 } & Komitmen terhadap kesepakatan kontrak. \\
\hline
\end{tabular}

\section{Sumber : IKPP, 2020}

3. Penetapan Alternatif Supplier

Alternatif terletak pada level 2 hirarki, Terdapat 4 supplier yang akan dipilih dari yang terbaik.

Tabel 6 Supplier Chemical Boilout Dan Masa Pasok Selama 5 Tahun Terakhir

\begin{tabular}{|l|l|l|}
\hline No & Supplier & \multicolumn{1}{c|}{ Waktu } \\
\hline 1 & Kemira & $2020-$ sekarang \\
\hline 2 & Buckman & $2018-2019$ \\
\hline 3 & Solenis & $2016-2017$ \\
\hline 4 & Amazone & $2015-2016$ \\
\hline
\end{tabular}

Sumber : IKPP, 2020

4. Membangun Hirarki

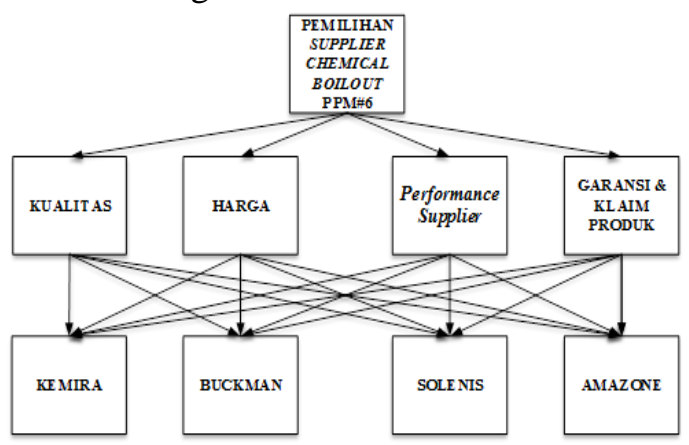

Gambar 3 Hirarki pemilihan supplier chemical boilout

Sumber : Pengolahan Data AHP

\subsection{Comparative Judgement}

Comparative judgement dilakukan dengan penilaian tentang kepentingan relatif dua elemen pada suatu tingkat tertentu dalam kaitannya dengan tingkatan diatasnya.

Untuk mendapatkan data tingkat kepentingan antar kriteria dan alternatif supplier terhadap kriteria-kriteria maka dilakukan pengisian oleh expert/PIC area chemical. 
- Hasil perhitungan kuesioner ke matriks perbandingan pasangan antar kriteria

Tabel 7. Kuisioner perbandingan pasangan antar kriteria

\begin{tabular}{|c|c|c|c|c|c|c|c|c|c|c|c|c|c|c|}
\hline \multirow[t]{2}{*}{ KRITERIA } & \multicolumn{13}{|c|}{ TINGKAT KEPENTINGAN } & \multirow[t]{2}{*}{ KRITERIA } \\
\hline & 9 & 8 & 6 & 5 & \begin{tabular}{|l|l}
4 & \\
\end{tabular} & & 1 & & & \begin{tabular}{l|l|l}
4 & 5 & 6
\end{tabular} & & 8 & 9 & \\
\hline Kualitas & & & & & & $\sqrt{v}$ & & & & & & & & Harga \\
\hline Kualitas & & W & & & & & & & & & & & & Garansi\&klaim \\
\hline Kualitas & & & & & & N & & & & & & & & Performance \\
\hline Harga & & & & W & & & & & & & & & & Garansi \& klaim \\
\hline Harga & & & & & & N & & & & & & & & Performance \\
\hline $\begin{array}{l}\text { Garansi \& } \\
\text { klaim }\end{array}$ & & & & & & & & W & & & & & & Performance \\
\hline
\end{tabular}

Sumber : Pengolahan Data 2020

Kuisioner kemudian disajikan dalam bentuk perhitungan untuk mencari pecahan desimal

Tabel 8. Perhitungan matriks perbandingan pasangan antar kriteria

\begin{tabular}{|l|c|c|c|c|}
\hline \multicolumn{1}{|c|}{ Kriteria } & Kualitas & Harga & $\begin{array}{c}\text { Garansi dan } \\
\text { klaim } \\
\text { produk }\end{array}$ & $\begin{array}{c}\text { Performance } \\
\text { Supplier }\end{array}$ \\
\hline Kualitas & $\mathbf{1}$ & $\mathbf{2}$ & $\mathbf{7}$ & $\mathbf{2}$ \\
\hline Harga & $\frac{1}{2}$ & $\mathbf{1}$ & $\mathbf{5}$ & $\mathbf{2}$ \\
\hline $\begin{array}{l}\text { Garansi dan } \\
\text { klaim produk }\end{array}$ & $\frac{1}{7}$ & $\frac{1}{2}$ & 1 & $\frac{1}{3}$ \\
\hline $\begin{array}{l}\text { Performance } \\
\text { Supplier }\end{array}$ & $\frac{1}{2}$ & $\frac{1}{2}$ & $\mathbf{3}$ & $\mathbf{1}$ \\
\hline
\end{tabular}

\section{Sumber : Pengolahan Data 2020}

Maka didapatlah hasil pecahan desimal sebagai berikut.

Tabel 9. Matriks perbandingan pasangan antar kriteria

\begin{tabular}{|l|c|c|c|c|}
\hline \multicolumn{1}{|c|}{ Kriteria } & Kualitas & Harga & $\begin{array}{c}\text { Garansi dan } \\
\text { klaim } \\
\text { produk }\end{array}$ & $\begin{array}{c}\text { Performance } \\
\text { Supplier }\end{array}$ \\
\hline Kualitas & $\mathbf{1}$ & $\mathbf{2}$ & $\mathbf{7}$ & $\mathbf{2}$ \\
\hline Harga & $\mathbf{0 , 5}$ & $\mathbf{1}$ & $\mathbf{5}$ & $\mathbf{2}$ \\
\hline $\begin{array}{l}\text { Garansi dan } \\
\text { klaim produk }\end{array}$ & $\mathbf{0 , 1 4 3}$ & $\mathbf{0 , 2}$ & $\mathbf{1}$ & $\mathbf{0 , 3}$ \\
\hline $\begin{array}{l}\text { Performance } \\
\text { Supplier }\end{array}$ & $\mathbf{0 , 5}$ & $\mathbf{0 , 5}$ & $\mathbf{3}$ & $\mathbf{1}$ \\
\hline
\end{tabular}

\section{Sumber : Pengolahan Data 2020}

Dengan perhitungan yang sama kemudian didapatlah hasil perhitungan kuisioner lainnya:

- Hasil perhitungan kuesioner ke matriks perbandingan pasangan dari tiap alternatif untuk kriteria kualitas.
Tabel 10. Matriks perbandingan pasangan tiap alternatif untuk kriteria kualitas

\begin{tabular}{|l|c|c|c|c|}
\hline Alternatif & Kemira & Buckman & Solenis & Amazone \\
\hline Kemira & 1 & 2 & 7 & 3 \\
\hline Buckman & 0,5 & 1 & 6 & 3 \\
\hline Solenis & 0,143 & 0,16 & 1 & 0,5 \\
\hline Amazone & 0,33 & 0,33 & 2 & 1 \\
\hline
\end{tabular}

Sumber : Pengolahan Data 2020

- Hasil perhitungan kuesioner ke matriks perbandingan pasangan dari tiap alternatif untuk kriteria Harga.

Tabel 11. Matriks perbandingan pasangan tiap alternatif untuk kriteria Harga

\begin{tabular}{|c|c|c|c|c|}
\hline Alternatif & Kemira & Buckman & Solenis & Amazone \\
\hline Kemira & 1 & 0,33 & 0,143 & 0,33 \\
\hline Buckman & 3 & 1 & 0,2 & 0,33 \\
\hline Solenis & 7 & 5 & 1 & 3,0 \\
\hline Amazone & 3 & 3 & 0,33 & 1 \\
\hline
\end{tabular}

\section{Sumber : Pengolahan Data 2020}

- Hasil perhitungan kuesioner ke matriks perbandingan pasangan dari tiap alternatif untuk kriteria Garansi dan Klaim Produk.

Tabel 12. Matriks perbandingan pasangan tiap alternatif untuk kriteria Garansi dan Klaim Produk

\begin{tabular}{|c|c|c|c|c|}
\hline Alternatif & Kemira & Buckman & Solenis & Amazone \\
\hline Kemira & 1 & 2 & 5 & 2 \\
\hline Buckman & 0,5 & 1 & 4 & 0,5 \\
\hline Solenis & 0,2 & 0,25 & 1 & 0,2 \\
\hline Amazone & 0,5 & 2 & 5 & 1 \\
\hline
\end{tabular}

\section{Sumber : Pengolahan Data 2020}

- Hasil perhitungan kuesioner ke matriks perbandingan pasangan dari tiap alternatif untuk kriteria Performance Supplier. 
Tabel 13. Matriks perbandingan pasangan tiap alternatif untuk kriteria Performance Supplier

\begin{tabular}{|c|c|c|c|c|}
\hline Alternatif & Kemira & Buckman & Solenis & Amazone \\
\hline Kemira & 1 & 0,3 & 3 & 2 \\
\hline Buckman & 3 & 1 & 5 & 4 \\
\hline Solenis & 0,3 & 0,2 & 1 & 0,3 \\
\hline Amazone & 0,5 & 0,25 & 3 & 1 \\
\hline
\end{tabular}

Sumber : Pengolahan Data 2020

\subsection{Synthesis of priority}

Synthesis of priority dilakukan dengan eigen vector method untuk mendapatkan bobot relatif bagi unsur-unsur pengambilan keputusan atau dengan kata lain dengan mengalikan prioritas lokal dengan prioritas dari kriteria yang bersangkutan di level atasnya dan menambahkannya ke tiap elemen dalam level yang dipengaruhi kriteria.

Berikut adalah tahapan Sythesis of Priority:

1. Menjumlahkan nilai dari setiap kolom pada matriks.

2. Membagi setiap nilai dari kolom dengan total kolom yang bersangkutan untuk memperoleh normalisasi matriks.

3. Menjumlahkan nilai dari setiap baris dan membagi dengan jumlah elemen untuk mendapatkan nilai rata-rata.

Berikut adalah hasil dari tahap syntesis off priority :

- Eigen Vektor Matriks Perbandingan Pasangan Antar Kriteria

1. Menjumlahkan nilai kolom dari matriks, berikut adalah hasil penjumlahan tiap kolom pada matriks perbandingan pasangan antar kriteria.
Tabel 14. Penjumlahan nilai kolom matriks perbandingan pasangan antar kriteria

\begin{tabular}{|l|c|c|c|c|}
\hline \multicolumn{1}{|c|}{ Kriteria } & Kualitas & Harga & $\begin{array}{c}\text { Garansi dan } \\
\text { klaim } \\
\text { produk }\end{array}$ & $\begin{array}{c}\text { Performance } \\
\text { Supplier }\end{array}$ \\
\hline Kualitas & 1 & 2 & 7 & 2 \\
\hline Harga & 0,5 & 1 & 5 & 2 \\
\hline $\begin{array}{l}\text { Garansi dan klaim } \\
\text { produk }\end{array}$ & 0,143 & 0,2 & 1 & 0,3 \\
\hline $\begin{array}{l}\text { Performance } \\
\text { Supplier }\end{array}$ & 0,5 & 0,5 & 3 & 1 \\
\hline JUMLAH & $\mathbf{2 , 1}$ & $\mathbf{3 , 7}$ & $\mathbf{1 6}$ & $\mathbf{5 , 3}$ \\
\hline
\end{tabular}

\section{Sumber : Pengolahan Data 2020}

Setelah menjumlahkan maka tahap selanjutnya adalah membagi setiap nilai kriteria dengan jumlah kolom. Maka didapatlah hasil berikut.

Tabel 15. Hasil pembagian tiap nilai terhadap jumlah kolom matriks perbandingan pasangan antar kriteria

\begin{tabular}{|l|c|c|c|c|}
\hline \multicolumn{1}{|c|}{ Kriteria } & Kualitas & Harga & $\begin{array}{c}\text { Garansi dan } \\
\text { klaim } \\
\text { produk }\end{array}$ & $\begin{array}{c}\text { Performan } \\
\text { ce } \\
\text { Supplier }\end{array}$ \\
\hline Kualitas & 0,467 & 0,541 & 0,438 & 0,375 \\
\hline Harga & 0,233 & 0,270 & 0,313 & 0,375 \\
\hline $\begin{array}{l}\text { Garansi dan } \\
\text { klaim produk }\end{array}$ & 0,067 & 0,054 & 0,063 & 0,056 \\
\hline $\begin{array}{l}\text { Performance } \\
\text { Supplier }\end{array}$ & 0,233 & 0,135 & 0,188 & 0,189 \\
\hline
\end{tabular}

\section{Sumber : Pengolahan Data 2020}

Kemudian menjumlahkan nilai dari setiap baris dan membagi dengan jumlah elemen untuk mendapatkan nilai rata rata sebagai eigen vektor syintesis prioritas antar kriteria. Berikut adalah hasilnya:

Tabel 16. Eigen Vektor matriks perbandingan pasangan antar kriteria

\begin{tabular}{|l|c|c|}
\hline \multicolumn{1}{|c|}{ Kriteria } & \multicolumn{1}{c|}{ Penjumlahan } & Eigen Vektor \\
\hline Kualitas & $(0,467+0,541+0,438+0,375) / 4$ & 0,455 \\
\hline Harga & $(0,233+0,270+0,313+0,375) / 4$ & 0,298 \\
\hline Garansi ian klaim produk & $(0,067+0,054+0,063+0,056) / 4$ & 0,061 \\
\hline Performance Supplier & $(0,233+0,135+0,188+0,188) / 4$ & 0,186 \\
\hline \multicolumn{2}{|c|}{ Jumlah } & 1 \\
\hline
\end{tabular}

Sumber : Pengolahan Data 2020

Dengan tahapan perhitungan yang sama maka didapatlah hasil Eigen vektor sebagai berikut : 
Tabel 17. Rekapitulasi hasil Eigen Vektor

\begin{tabular}{|l|c|}
\hline \multicolumn{2}{|c|}{ Eigen Vektor Perbandingan Pasangan Antar Kriteria } \\
\hline Alternatif & Eigen Vektor \\
\hline Kualitas & 0,455 \\
\hline Harga & 0,298 \\
\hline Garansi & 0,061 \\
\hline Performance & 0,186 \\
\hline Jumlah & 1 \\
\hline \multicolumn{2}{|c|}{ Eigen Vektor Perbandingan Pasangan Untuk Kriteria Kualitas } \\
\hline Alternatif & Eigen Vektor \\
\hline Kemira & 0,479 \\
\hline Buckman & 0,328 \\
\hline Solenis & 0,062 \\
\hline Amazone & 0,131 \\
\hline Jumlah & 1 \\
\hline \multicolumn{2}{|c|}{ Eigen Vektor Perbandingan Pasangan Untuk Kriteria Harga } \\
\hline Alternatif & Eigen vektor \\
\hline Kemira & 0,066 \\
\hline Buckman & 0,128 \\
\hline Solenis & 0,569 \\
\hline Amazone & 0,237 \\
\hline Jumlah & 1 \\
\hline Eigen Vektor Perbandingan Pasangan Untuk Kriteria Garansi \& Klaim Produk \\
\hline Alternatif & Eigen Vektor \\
\hline Kemira & 0,427 \\
\hline Buckman & 0,205 \\
\hline Solenis & 0,065 \\
\hline Amazone & 0,303 \\
\hline Jumlah & 1 \\
\hline Eigen Vektor Perbandingan Pasangan Untuk Kriteria Performance Supplier \\
\hline Alternatif & Eigen Vektor \\
\hline Kemira & 0,229 \\
\hline Buckman & 0,536 \\
\hline Solenis & 0,077 \\
\hline Amazone & 0,157 \\
\hline Jumlah & 1 \\
\hline Sumbr| & Data 2020 \\
\hline
\end{tabular}

\section{Sumber : Pengolahan Data 2020}

\subsection{Logical Consistency}

Logical consistency merupakan karakteristik penting AHP. Hal ini dicapai dengan mencari nilai konsistensi dan mengagresikan seluruh eigen vector yang diperoleh dari berbagai tingkatan hirarki dan selanjutnya diperoleh suatu vektor composite tertimbang yang menghasilkan urutan pengambilan keputusan.

\subsubsection{Nilai Konsistensi}

- Nilai Konsistensi perhitungan eigen vektor antar Kriteria a. Mengalikan matriks perbandingan pasangan dengan eigen vektor

$\left[\begin{array}{cccc}1 & 2 & 7 & 2 \\ 0,5 & 1 & 5 & 2 \\ 0,14 & 0,2 & 1 & 0,3 \\ 0,5 & 0,5 & 3 & 1\end{array}\right] \times \quad \times \quad\left[\begin{array}{l}0,455 \\ 0,298 \\ 0,061 \\ 0,186\end{array}\right]=$
$\left[\begin{array}{l}1,852 \\ 1,204 \\ 0,247 \\ 0,746\end{array}\right]$

b. Hasil perkalian dibagi dengan eigen vektor

$\left[\begin{array}{l}1,852 \\ 1,204 \\ 0,247 \\ 0,746\end{array}\right]:\left[\begin{array}{l}0,455 \\ 0,298 \\ 0,061 \\ 0,186\end{array}\right]=\left[\begin{array}{l}4,071 \\ 4,043 \\ 4,035 \\ 4,016\end{array}\right]$

c. Jumlahkan setiap hasil dari pembagian tersebut dan bagi dengan jumlah banyaknya kriteria. Maka didapatlah hasil $\lambda$ maksimum.

$(4,071+4,043+4,035+4,016) / 4=4,041$

d. Menghitung indeks konsistensi (Consistency Index $=\mathrm{CI}$ )

$\mathrm{CI}=(\lambda$ maks $-\mathrm{n}) /(\mathrm{n}-1)$

$\mathrm{CI}=(4,041-4) /(4-1)=0,0139$

e. Menghitung rasio konsistensi $($ Consistency Ratio $=\mathrm{CR})$

$\mathrm{CR}=\mathrm{CI} / \mathrm{RI}$

Tabel 15. Tabel Random Consistensy Index (RI)

\begin{tabular}{|c|c|c|c|c|c|c|c|c|c|c|}
\hline $\mathrm{N}$ & 1 & 2 & 3 & 4 & 5 & 6 & 7 & 8 & 9 & 10 \\
\hline $\mathrm{RI}$ & 0 & 0 & 0,6 & 0,9 & 1,1 & 1,2 & 1,32 & 1,41 & 1,5 & 1,5 \\
\hline
\end{tabular}

Sumber : Thomas L. Saaty, 1994

$\mathrm{CR}=\mathbf{0 , 0 1 3 9} / \mathbf{0 , 9}=\mathbf{0 , 0 1 5 5}$

Karena nilai CR <0,1 (10\%) Maka dapat diterima, artinya matriks perbandingan berpasangan antar kriteria telah diisi dengan pertimbangan yang konsisten

Dengan perhitungan nilai konsistensi yang sama maka didapatlah rekapitulasi hasil konsistensi sebagai berikut: 
Tabel 18. Rekapitulasi hasil Konsistensi

\begin{tabular}{|l|c|c|c|l|}
\hline & CI & RI & $\begin{array}{l}\text { Konsistensi } \\
=\text { CI/RI }\end{array}$ & Keterangan \\
\hline $\begin{array}{l}\text { Nilai Konsistensi } \\
\text { perhitungan } \\
\text { eigen vektor } \\
\text { antar Kriteria }\end{array}$ & 0,01 & 0,9 & 0,015 & $\begin{array}{l}\text { CR }<0,1(10 \%) \\
\text { Maka data dan } \\
\text { perhitungan } \\
\text { konsisten }\end{array}$ \\
\hline $\begin{array}{l}\text { Nilai Konsistensi } \\
\text { perhitungan } \\
\text { eigen vektor tiap } \\
\text { alternatif untuk } \\
\text { kriteria kualitas }\end{array}$ & 0,02 & 0,9 & 0,018 & $\begin{array}{l}\text { CR <0,1 (10\%) } \\
\text { Maka data dan } \\
\text { perhitungan } \\
\text { konsisten }\end{array}$ \\
\hline $\begin{array}{l}\text { Nilai Konsistensi } \\
\text { perhitungan } \\
\text { eigen vektor tiap } \\
\text { alternatif untuk } \\
\text { kriteria harga }\end{array}$ & 0,04 & 0,9 & 0,043 & $\begin{array}{l}\text { CR <0,1 (10\%) } \\
\text { Maka data dan } \\
\text { perhitungan } \\
\text { konsisten }\end{array}$ \\
\hline $\begin{array}{l}\text { Nilai Konsistensi } \\
\text { perhitungan } \\
\text { eigen vektor tiap } \\
\text { alternatif untuk } \\
\text { kriteria garansi }\end{array}$ & 0,03 & 0,9 & 0,033 & $\begin{array}{l}\text { CR <0,1 (10\%) } \\
\text { Maka data dan } \\
\text { perhitungan } \\
\text { konsisten }\end{array}$ \\
\hline $\begin{array}{l}\text { Nilai Konsistensi } \\
\text { perhitungan } \\
\text { eigen vektor tiap } \\
\text { alternatif untuk } \\
\text { kriteria } \\
\text { performance }\end{array}$ & 0,04 & 0,9 & 0,042 & $\begin{array}{l}\text { CR <0,1 (10\%) } \\
\text { perhitungan dan } \\
\text { konsisten }\end{array}$ \\
\hline
\end{tabular}

\section{Sumber : Pengolahan Data 2020}

\subsubsection{Perangkingan Supplier}

Supllier terbaik adalah supplier yang memiliki nilai bobot terbesar dari supplier lainnya, kita dapat mengetahuinya dengan cara:

1. Mengalikan nilai eigen vektor tiap alternatif dengan eigen vektor kriteria.

$\begin{array}{rlll}\text { Kemira } & 0,478 & 0,065 & 0,427 \\ \text { Buckman }= & 0,328 & 0,128 & 0,204 \\ \text { Solenis }= & 0,062 & 0,568 & 0,064 \\ \text { Amazone }= & 0,130 & 0,237 & 0,302 \\ 0,454 & 0,306 & & \\ \mathbf{0 , 2 9 7} & 0,299 & & \\ \mathbf{0}_{0,061} & 0,216 & & \\ 0,185 & 0,177 & & \end{array}$

2. Maka didapatlah perangkingan supplier chemical boilout adalah

1. Kemira dengan bobot 0,306 atau $30,6 \%$

2. Buckman dengan bobot 0,299 atau 29,9 $\%$

3. Solenis dengan bobot 0,216 atau $21,6 \%$

4. Amazone dengan bobot 0,177 atau 17,7 $\%$

\section{Kesimpulan}

Setelah melakukan pengolahan data maka didapatlah kesimpulan yang menjawab tujuan dari penelitian ini yaitu :

1. Kriteria yang didapatkan setelah melakukan pengambilan data dari expert dan mengolahnya dengan metode (AHP) maka kriteria atau level 1 pada hirarki berjumlah 4, yaitu : Kualitas, harga, garansi dan klaim produk dan performance supplier, dimana hasil untuk nilai bobot prioritas / nilai rata rata tiap kriteria yaitu, kualitas $(0,455)$, harga (0.298) garansi dan klaim produk $(0,061$ dan performance supplier $(0,186)$. dengan urutan kepentingan kriteria yaitu Kualitas, Harga, Performance Supplier dan Garansi dan Klaim Produk.

2. Hasil dari bobot alternatif / supplier yang didapatkan yaitu Kemira (0,30627), Buckman (0,216081), Performance Supplier $(0,177918)$ dan Garansi dan Klaim Produk $(0,299731)$. Sehingga supplier terbaik yang terpilih dengan metode Analitycal Hierarhy Process adalah Supplier Kemira.

\section{Daftar Pustaka}

[1] Hardiyanti, Annisaa, Putri. 2016. Model Pemilihan Moda Dengan Metode Ahp (Analytical Hierarchy Process). 0,\$2\&karta : Universitas Muhammadiyah 0,\$8gkarta.

\section{0,077}

0, 157 Situmorang, Juni, yanti. 2017. Sistem Pendukung Keputusan Pemilihan Merek Laptop Menggunakan Metode Analytical Hierarchy Process (Ahp). Jakarta : STMIK Nusa Mandiri.

[3] Handayani, Irma, Yani \& Darmianti, Yuni 2017 "Pemilihan Supplier Bahan Baku Bangunan Dengan Metode Analytical Hierarchy Process (Ahp) Pada Pt. Cipta Nuansa Prima Tangerang", Vol 14, No 1

[4] Saputra, Tio, Kuntara. 2018. Penentuan Kriteria Dalam Pemilihan Supplier Bahan Kain Pada Industri Textile Dengan Menggunakan Metode Analytical 
Hierarchy Process (Ahp). Yogyakarta : Universitas Islam Indonesia

[5] Umbara, Raditya, Panji 2016 "Metode Analytic Hierarchy Process Dalam Menentukan Pembobotan Faktor-Faktor Yang Mempengaruhi Kerentanan Gedung Di Dki Jakarta Terhadap Ancaman Gempa", Vol 11, No 2 